\title{
PENURUNAN NILAI COD PADA PESTISIDA SIPERMETRIN DENGAN FOTOKATALIS TITANIUM(IV) OKSIDA-PLATINA
}

\section{REDUCTION OF COD IN CYPERMETHRIN PESTICIDE USING PHOTOCATALYST TITANIUM(IV) OXIDE - PLATINA}

\author{
Diana Rakhmawaty Eddy*, Adhitya Pratama, Atiek Rostika Noviyanti \\ Program Studi S1 Kimia, Departemen Kimia Fakultas MIPA Universitas Padjadjaran \\ J1. Raya Bandung Sumedang Km 21 Jatinangor 45363. Tlp/Fax. 0227794391 \\ *e-mail: diana.rahmawati@unpad.ac.id
}

\begin{abstract}
ABSTRAK
Pada penelitian ini telah dilakukan fotodegradasi pestisida jenis sipermetrin dengan adanya fotokatalis titanium (IV) oksida-platina. Fotokatalis tersebut dibuat dengan merefluks larutan titanium(IV) oksida tetraminplatina(II) klorida selama 2 jam kemudian diuapkan pelarutnya dan dipanaskan selama 12 jam. Padatan fotokatalis kemudian dikalsinasi selama 3 jam pada $500{ }^{\circ} \mathrm{C}$. Hasil sintesis titanium(IV) oksida-platina $0,5 \%$ dan $1 \%$ dikarakterisasi dengan XRD, SEM, dan SEM-EDX. Kemampuan dalam mengkatalisis fotodegradasi diuji untuk pestisida sipermetrin yang dilakukan selama 4 jam. Hasil fotodegradasi dinyatakan sebagai COD (Chemical Oxygen Demand) yang diukur setiap 1 jam. Penurunan COD terbesar untuk titanium(IV) oksida platina $0,5 \%$ dan titanium(IV) oksida-platina $1 \%$ masing-masing yaitu 77\% dan 79\%. Sementara $\mathrm{TiO}_{2}$ standar sebesar 68,42\%. Fotokatalis titanium(IV) oksida-platina lebih baik dibanding titanium(IV) oksida untuk degradasi sipermetrin.
\end{abstract}

Kata kunci: Fotokatalisis, pestisida sipermetrin, titanium (IV) oksida-platina

\begin{abstract}
This study has been conducted cypermethrin pesticide photodegradation in the presence of the photocatalyst titanium (IV) oxide - platinum. The photocatalyst prepared by refluxing a solution of titanium (IV) oxide tetraminplatina (II) chloride for 2 hours and then evaporated the solvent and heated for 12 hours. Solids photocatalyst then calcined for $3 \mathrm{~h}$ at $500{ }^{\circ} \mathrm{C}$. The results of the synthesis of titanium ( IV ) oxide - platinum $0.5 \%$ and $1 \%$ were characterized by XRD, SEM, and SEM - EDX. Ability to catalyze photodegradation tested for pesticide cypermethrin conducted for 4 hours. Photodegradation results expressed as COD (Chemical Oxygen Demand) were measured every 1 hour. Greatest COD reduction for titanium (IV) oxide $0.5 \%$ platinum and titanium (IV) oxide - platinum $1 \%$ respectively of $77 \%$ and $79 \%$. While the standard of $68.42 \% \mathrm{TiO}_{2}$. Photocatalyst titanium (IV) oxide - platinum better than titanium (IV) oxide for cypermethrin degradation.
\end{abstract}

Keywords: Pesticides cypermethrin, photocatalysis, titanium(IV) oxide-platinum

\section{PENDAHULUAN}

Indonesia merupakan negara agraris yang banyak menggunakan tanahnya pada bidang pertanian dan perkebunan. Pertanian di Indonesia banyak menggunakan pestisida untuk mendapatkan hasil yang maksimal 
karena pestisida digunakan untuk mengendalikan jasad renik pengganggu seperti hama, penyakit atau gulma yang dapat mengurangi hasil pertanian (Girsang, 2009).

Penggunaan pestisida di bidang pertanian dan perkebunan pada beberapa tahun lalu mengalami peningkatan secara kuantitas dan kualitas serta bertambahnya juga perusahaan yang membuat pestisida sintesis (Kundua, et. $a l ., 2005)$. Sebagian besar pestisida yang mencemari lingkungan merupakan senyawa organik yang sulit untuk didegradasi (Persistent Organic Pollutants) (Kaushik, et. al., 2010).

Salah satu contoh pestisida sintesis yaitu sipermetrin yang merupakan golongan insektisida piretroid. Sipermetrin diklasifikasikan sebagai piretroid golongan II karena memiliki gugus $\alpha$-siano. Berdasarkan data pada Kementeri Pertanian Indonesia pada tahun 2004 sudah terdapat 16 perusahaan yang memproduksi sipermetrin dengan jumlah yang besar. Sipermetrin memiliki toksisitas yang relatif rendah untuk mamalia dan burung tetapi memiliki toksisitas yang tinggi untuk ikan (Mills-Groninger, et. al., 2012).

Saat ini sudah banyak metode yang digunakan untuk mengurangi cemaran pestisida secara biologis dan kimiawi. Secara kimiawi banyak menggunakan proses oksidasi tingkat lanjut (Advance Oxidation Processes) seperti penggunaan fotokatalis untuk fotodegradasi. Fotodegradasi banyak digunakan karena energi yang digunakan untuk degradasi bisa didapat dari radiasi cahaya. Fotokatalis dapat melakukan fotodegradasi senyawa organik dengan membentuk radikal hidroksida yang akan mendegradasi pencemaran senyawa organik. Fotokatalis yang banyak digunakan untuk fotodegradasi yaitu titanium(IV) oksida, pereaksi fenton dan hidrogen peroksida karena dapat menghasilkan radikal hiroksida (Mills and Hunte, 1997).

Titanium(IV) oksida memiliki keuntungan yang relatif lebih murah secara komersial, stabil dan tidak mencemari lingkungan (Mills and Hunte, 1997). Tetapi titanium(IV) oksida memiliki band gap yang cukup besar yaitu 3,2 eV sehingga membutuhkan energi aktivasi yang cukup besar sehingga dapat diberi doping berupa logam untuk menurunkan energi aktivasinya. Beberapa doping yang dapat diberikan pada titanium(IV) oksida yaitu berupa logam mulia (platina, emas, dan perak) dan beberapa unsur nonlogam (nitrogen, sulfur, dan karbon) (Zaleska, 2008). Pada penelitian oleh Wei, et. al., (2012) menggunakan doping platina untuk meningkatkan fotokatalitik dan menurunkan energi aktivasi dari titanium(IV) oksida sehingga dapat lebih baik untuk mengurangi pencemaran lingkungan.

Tujuan umum dari penelitian ini adalah membuat fotokatalis titanium(IV) oksida-platina yang digunakan untuk fotodegradasi pestisida sipermetrin. Tujuan khusus dari penelitian adalah untuk mengetahui komposisi titanium(IV) oksida-platina yang memiliki aktivitas fotodegradasi pestisida tertinggi.

\section{METODE PENELITIAN}

Alat yang digunakan dalam penelitian ini adalah SEM-EDX, XRD, evaporator vakum, lampu UV $\mathrm{Hg}$, tanur, oven, tabung kuarsa, rangkaian alat refluks, dan alat-alat gelas.

Bahan yang digunakan dalam penelitian ini adalah titanium(IV) oksida Degussa P25, tetraminplatina(II) klorida monohidrat, kalium dikromat, ammonium besi(II) sulfat heksahidrat, asam sulfat, difenilamin, pestisida 
sipermetrin, kertas saring Whatman 42, dan akuades.

\section{Sintesis Titanium(IV) oksida-Platina}

Fotokatalis disintesis dengan variasi berat platina (dari garamnya yaitu tetraminplatina(II) klorida monohidrat) $0,5 \%$ dan $1 \%$ (b/b) dengan berat total fotokatalis 3 gram. Prosedur yang dilakukan dengan mencampur titanium(IV) oksida, tetraminplatina(II) klorida monohidrat dan akuades gelas kimia. Kemudian direfluks selama 3 jam dengan suhu $80{ }^{\circ} \mathrm{C}$. Setelah itu diuapkan pelarutnya dengan evaporator vakum dan kemudian dikeringkan dengan oven pada suhu $110{ }^{\circ} \mathrm{C}$ selama $12 \mathrm{jam}$. Setelah terbentuk padatan dikalsinasi pada 500 ${ }^{\circ} \mathrm{C}$ selama 3 jam pada udara terbuka. Fotokatalis yang terbentuk dianalisis dengan SEM-EDS dan XRD.

\section{Pengujian Fotokatalitik Titanium(IV) oksida-Platina dengan Pestisida}

Larutan sipermetrin dibuat konsentrasi 25 ppm sebanyak 1 liter. Larutan diambil $50 \mathrm{~mL}$ dan dimasukkan ke tabung kuarsa kemudian ditambah 50 $\mathrm{mg}$ fotokatalis (fotokatalis yang digunakan titanium(IV) oksida, titanium(IV) oksida- platina $0,5 \%$ dan titanium(IV) oksida-platina 1\%). Setelah itu diiradiasi dengan lampu UV selama 4 jam dan dilakukan pengambilan sampel setiap 1 jam. Sampel yang didapatkan diencerkan 200 kali faktor pengenceran kemuadian diambil 0,5 mL untuk diukur nilai COD. Setelah itu dihitung penurunan COD untuk masing-masing fotokatalis.

\section{HASIL DAN PEMBAHASAN}

\section{Sintesis Titanium(IV) Oksida-Platina}

Fotokatalis titanium(IV) oksidaplatina disintesis dengan menggunakan
titanium(IV) oksida Degussa P25 dengan tetraminplatina(II) klorida monohidrat sebagai sumber platina dengan metode impregnasi. Fotokatalis disintesis dengan berat total 3 gram dan variasi berat platina sebesar $0,5 \%$ dan $1 \%$ dari berat total.

Metode impregnasi digunakan karena ingin membentuk co-catalyst platina pada titanium(IV) oksida. Dari setiap reaktan dilarutkan dengan akuades dan direfluks pada suhu $80{ }^{\circ} \mathrm{C}$ selama 3 jam sambil diaduk. Pada saat refluks terjadi masuknya ion Pt pada permukaan titanium(IV) oksida karena ada sisi aktif Ti-O- dari titanium(IV) oksida yang terbuka dengan adanya pelarut (O'Shea, 2013).

Setelah direfluks, larutan diuapkan pelarutnya dengan evaporator vakum hingga didapat padatannya. Kemudian dikeringkan pada suhu $110^{\circ} \mathrm{C}$ selama 12 jam untuk menghilangkan pelarut akuades yang masih ada dalam padatan. Setelah kering padatan dikalsinasi dengan tanur pada suhu 500 ${ }^{\circ} \mathrm{C}$ selama 3 jam. Pada saat kalsinasi ini terjadinya pemadatan dari katalis karena senyawa lain yang berasal dari prekursor lepas karena suhu tinggi sehingga ion platina dapat lebih masuk pada titanium(IV) oksida.

Setelah dibuat fotokatalis titanium(IV) oksida-platina dengan variasi berat platina $0,5 \%$ dan $1 \%$ dari berat total terjadi perubahan warna dari putih (warna titanium(IV) oksida) menjadi abu-abu muda pada titanium(IV) oksida-platina $0,5 \%$ dan menjadi warna abu-abu pada titanium(IV) oksida-platina 1\%. Hasil sintesis katalis dapat dilihat pada Gambar 1. 

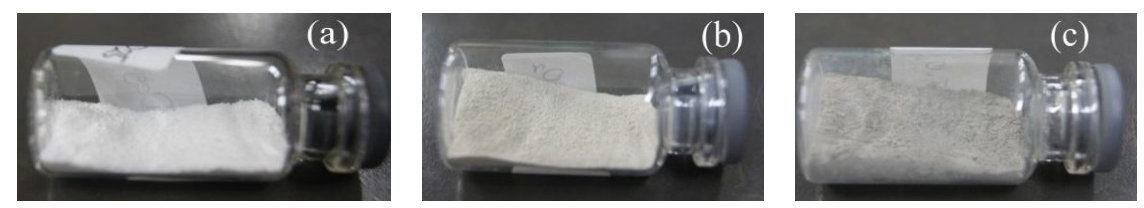

Gambar 1. Foto (a) titanium(IV) oksida Degussa P25, (b) hasil sintesis titanium(IV) oksida-platina $0,5 \%$, dan (c) titanium(IV) oksida-platina $1 \%$.

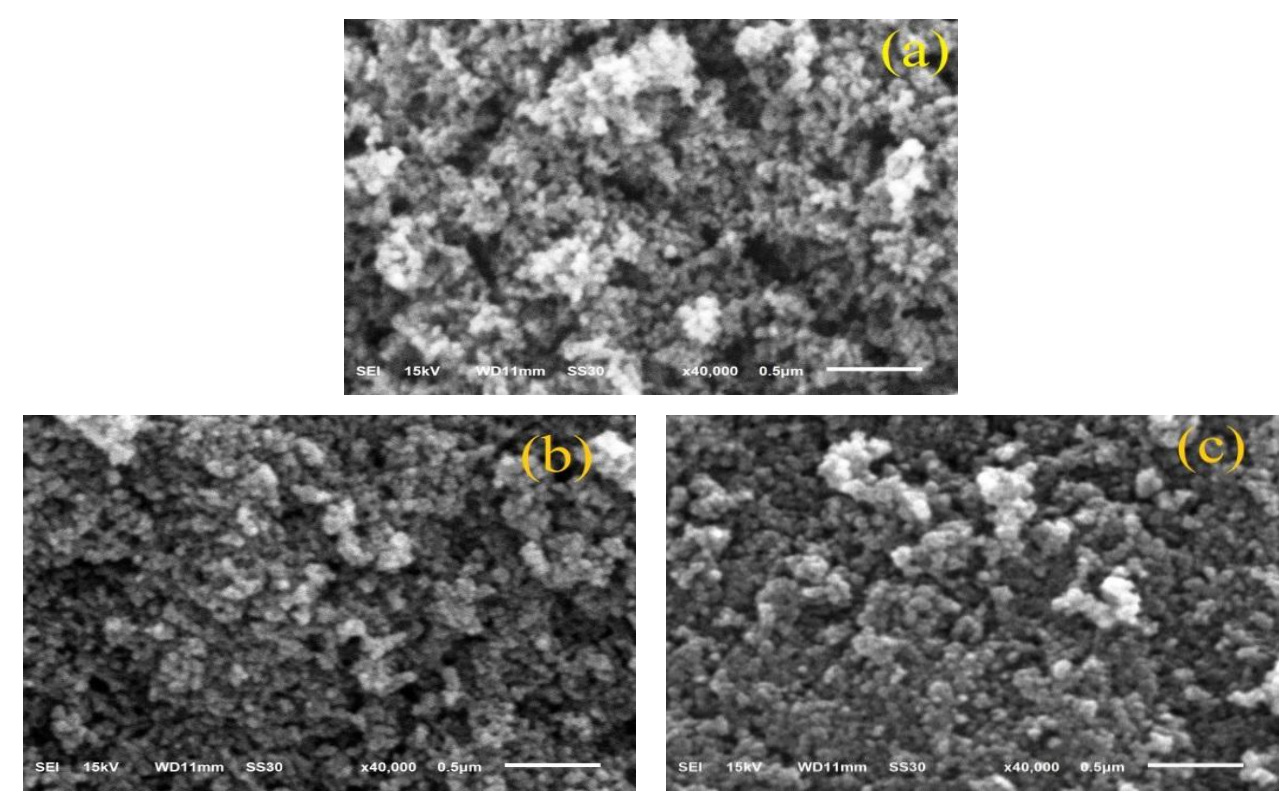

Gambar 2. Hasil karakterisasi SEM : (a) titanium(IV) oksida, (b) titanium(IV) oksidaplatina $0,5 \%$, dan (c) titanium(IV) oksida-platina $1 \%$.

Berdasarkan hasil karakterisasi dengan SEM menunjukkan hasil bahwa titanium(IV) oksida-platina memiliki morfologi yang relatif sama dengan titanium(IV) oksida Degussa P25 karena jumlah platina realitif sedikit sehingga tidak mempengaruhi morfologi titanium(IV) oksida-platina yang bisa dilihat pada Gambar 2. Sedangkan hasil karakterisasi SEM-EDX menunjukkan jumlah platina yang terdapat dalam titanium(IV) oksida-platina bisa dilihat pada Gambar 3 dan Gambar 4.

Setelah itu titanium(IV) oksidaplatina dikarakterisasi dengan menggunakan XRD untuk membuktikan secara kualitatif adanya ion platina yang terdapat pada titanium(IV) oksidaplatina. Berdasarkan hasil karakterisasi dengan XRD pada Gambar 5, hanya terdapat pola difraksi dari titanium(IV) oksida dalam bentuk anatase dengan nilai $2 \theta$ pada $25,60^{\circ} ; \quad 39,23^{\circ}$; $49,34^{\circ} ; 54,82^{\circ} ; 55,02^{\circ}$; dan $63,52^{\circ}$ untuk anatase sesuai dengan PDF 21-1272 (anatase) dan bentuk rutil dengan nilai $2 \theta$ pada $27,32^{\circ}$ sesuai dengan PDF 21 1276 (rutil), sedangkan pola difraksi platina sesuai PDF 04-0802 terdapat puncak pada $2 \theta 39,68^{\circ} ; 46,25^{\circ} ; 67,18^{\circ}$; $80,62^{\circ}$ dan $85,31^{\circ}$ - tidak muncul. Hal ini terjadi kemungkinan karena jumlah platina yang terdapat pada fotokatalis terlalu sedikit sehingga terjadi tumpang tindih puncak platina dengan puncak titanium(IV) oksida juga karena dalam sampel $\mathrm{TiO}_{2}$ didominasi oleh anatase. Tidak munculnya puncak difraksi dapat disebabkan juga oleh rendahnya kristal tersebut atau Pt pada fotokatalis hasil preparasi tidak terbentuk kristal, dimana $\mathrm{Pt}$ pada $\mathrm{TiO}_{2}$ terjadi percampuran interaksi secara fisik. 

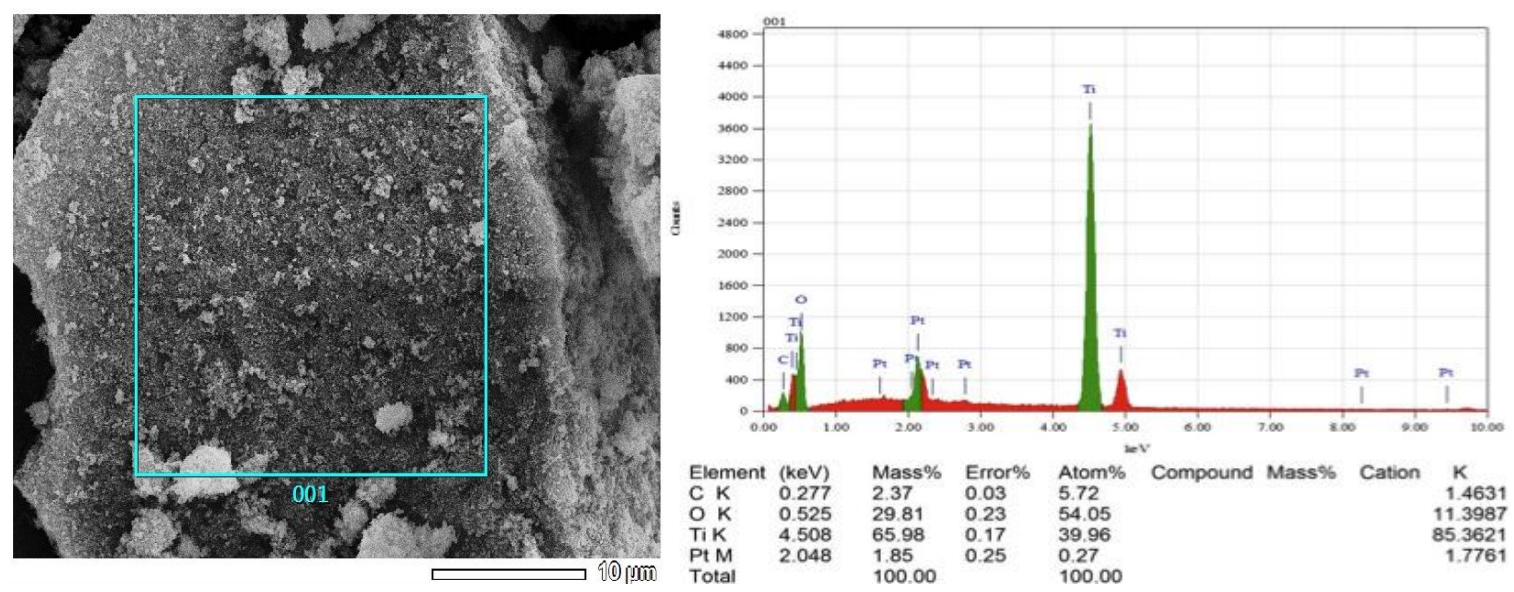

Gambar 3. Hasil karakterisasi SEM-EDX titanium(IV) oksida-platina 0,5\%.
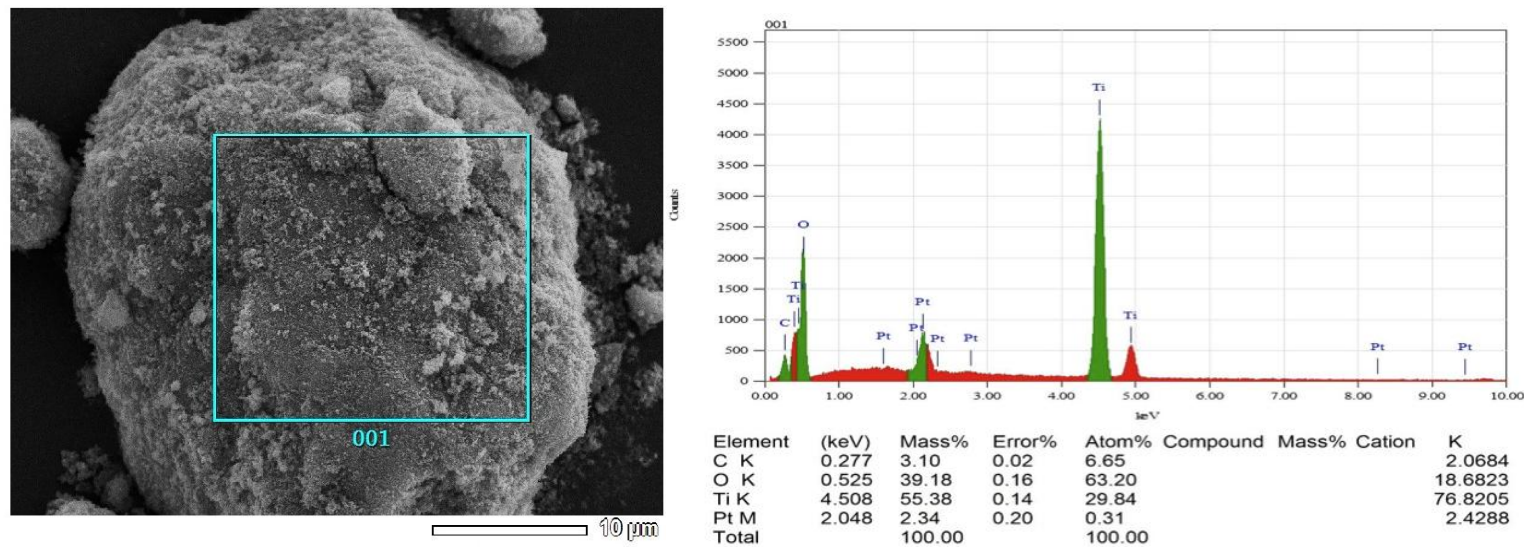

Gambar 4. Hasil karakterisasi SEM-EDX titanium(IV) oksida-platina $1 \%$.

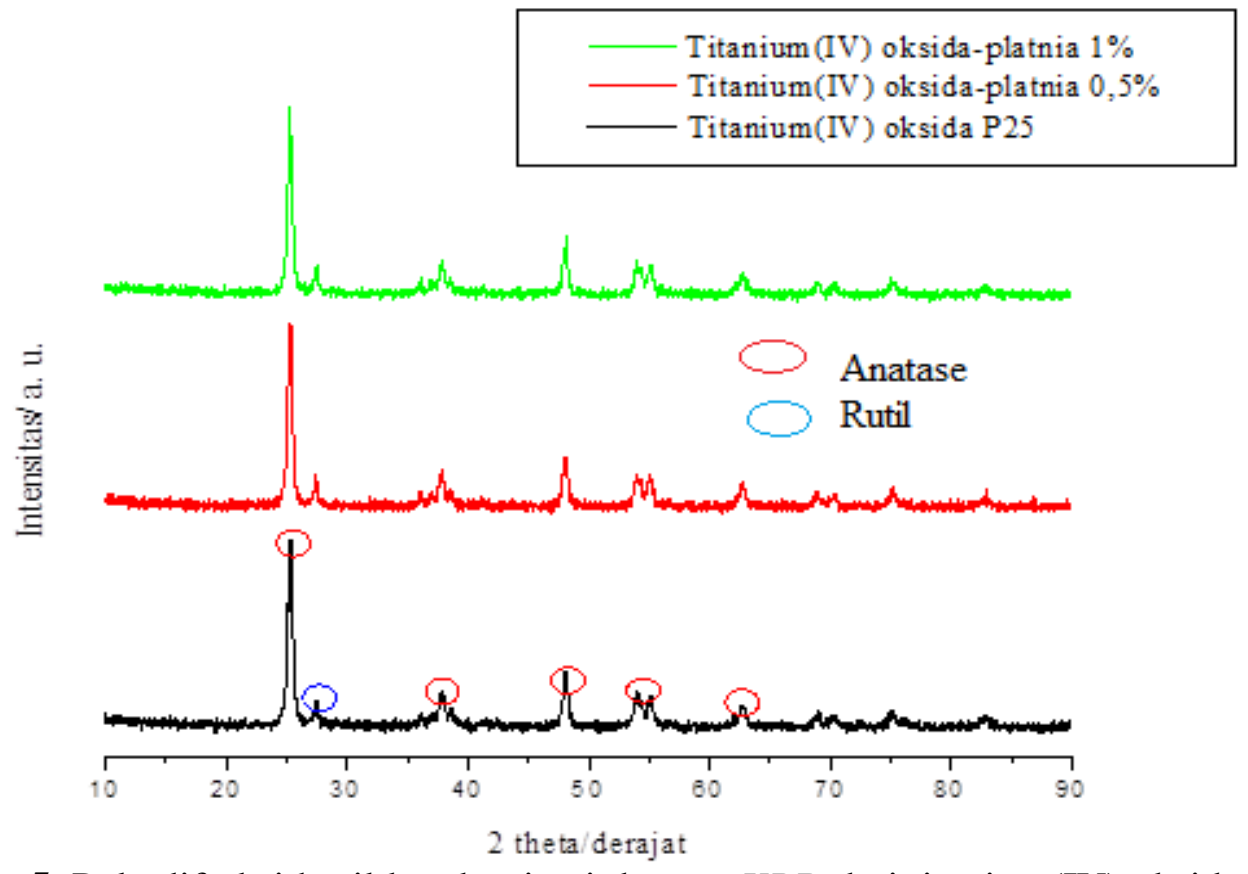

Gambar 5. Pola difraksi hasil karakterisasi dengan $X R D$ dari titanium(IV) oksida Degussa P25, titanium(IV) oksida-platina $0,5 \%$, dan titanium(IV) oksida-platina $1 \%$. 


\section{Pengujian Fotokatalitik Titanium(IV) oksida-Platina Dengan Pestisida}

Aktivitas fotokatalitik dari titanium(IV) oksida-platina diketahui dengan kemampuan fotodegradasi pestisida sipermetrin. Sipermetrin dipilih karena merupakan pestisida yang cukup banyak digunakan, di Indonesia pun banyak perusahaan yang membuat pestisida ini. Sipermetrin ini merupakan pestisida golongan organoklorin, struktur kimianyadapat dilihat pada Gambar 6. Golongan organoklorin ini bersifat stabil dan tidak mudah didegradasi secara alami.<smiles>CC1(C)C(C=C(Cl)Cl)C1C(=O)OC(C#N)c1cccc(Oc2ccccc2)c1</smiles>

Gambar 6.Struktur kimia sipermetrin

Larutan sipermetrin $250 \mathrm{ppm}$ dalam 1 liter akuades diambil $50 \mathrm{~mL}$ dan dimasukkan ke dalam tabung kuarsa yang telah berisi $50 \mathrm{mg}$ fotokatalis (variasi titanium(IV) oksida Degussa P25, titanium(IV) oksida-platina $0,5 \%$, dan titanium(IV) oksida-platina 1\%) kemudian diiradiasi dengan lampu UV $\mathrm{Hg}$ selama 4 jam yang diambil sampel setiap 1 jam dan diukur nilai CODnya.
Pengukuran COD digunakan karena dengan oksidator kalium dikromat dapat mengoksidasi senyawa organik yang merupakan potongan dari hasil fotodegradasi oleh fotokatalis sehingga dapat diketahui jumlah "beban oksidasi" dari sampel yang telah mengalami fotodegradasi dan karena pada penelitian ini tidak melakukan analisis senyawa hasil fotodegradasi maka dengan mengetahui nilai COD dapat mengetahui juga kemampuan fotokatalis untuk mengoksidasi larutan pestisida sipermetrin.

Hasil penurunan nilai COD dari setiap fotokatalis dapat dilihat pada Tabel 1. Dari hasil pengukuran COD terjadi penurunan setelah mengalami fotodegradasi terhadap nilai COD awal, setelah diiradiasi dengan lampu UV menunjukkan bahwa terjadi proses oksidasi pada saat diiradiasi lampu UV.

Titanium(IV) oksida Degussa P25 sebelum diiradiasi tidak bersifat sebagai fotokatalis, ketika terdapat larutan sampel atau air maka terbentuk ikatan hidrogen dapat dilihat ilustrasinya pada Gambar 7 dan ketika diiradiasi dengan energi 3,2 $\mathrm{eV}$ terjadi perpindahan elektron dari valence band menuju conduction band yang terdapat spesi hidroksida sehingga menyebabkan terbentuknya radikal hidroksida untuk proses fotodegradasi (Khataee \& Kasiri, 2010).

Tabel 1. Data penurunan nilai COD dari larutan pestisida dengan fotokatalis setelah diiradiasi selama 4 jam.

\begin{tabular}{cccc}
\hline Lama iradiasi/ Jam & \multicolumn{3}{c}{ Penurunan nilai COD untuk setiap fotokatalis/\% } \\
\cline { 2 - 4 } & $\mathbf{T i O}_{\mathbf{2}}$ & $\mathbf{0 , 5 \%} \mathbf{~ P t / T i O}$ & $\mathbf{1 \%} \mathbf{~ P t / T i O}$ \\
\hline 1 & 26,32 & 50,00 & 41,51 \\
2 & 42,11 & 59,09 & 60,38 \\
3 & 57,89 & 72,73 & 62,26 \\
4 & 68,42 & 77,27 & 79,25 \\
\hline
\end{tabular}




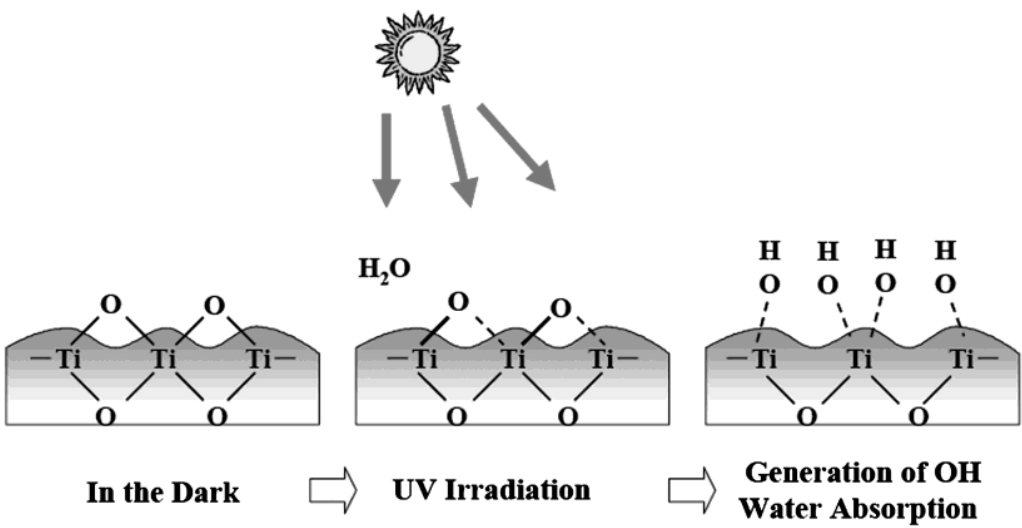

Gambar 7. Ilustrasi permukaan fotokatalis titanium(IV) oksida pada kondisi sebelum dan saat diiradiasi (Khataee \& Kasiri, 2010).

Setelah terjadi eksitasi elektron dari valence band menuju conduction band maka dapat terbentuk radikal hidroksida dari conduction band dan valence band, pada valence band ada kemungkinan terbentuknya radikal dari senyawa sipermetrin yang kehilangan sebuah elektron untuk menstabilkan valence band yang kehilangan satu elektron. Tetapi jika elektron yang tereksitasi pada conduction band dan hole pada valence band tidak membentuk radikal maka proses rekombinasi dari elektron padaconduction bandakan kembali pada valence band sehingga tidak terjadi reaksi fotodegradasi.

Penurunan nilai COD dengan menggunakan fotokatalis titanium(IV) oksida-platina lebih besar dibanding menggunakan fotokatalis titanium(IV) oksida Degussa P25 setelah diiradiasi selama 4 jam. Hal ini terjadi karena pengaruh platina yang membantu proses fotodegradasi. Platina yang terdapat pada titanium(IV) oksida-platina dapat meningkatkan proses fotodegradasi karena platina berfungsi sebagai cocatalyst yang dapat menurunkan energi band gap menjadi 3-2,9 eV sehingga perpindahan elektron dari conduction band ke valence band dapat lebih mudah dengan energi lebih rendah, platina juga mengurangi kemungkinan terjadi rekombinasi antara electron dan hole sehingga pembentukan reaksi radikal hidroksida atau reaksi redoks menjadi lebih baik. Platina pada titanium(IV) oksida juga berfungsi sebagai "pulau elektron" yang berfungsi mempertahankan electron untuk membentuk radikal seperti pada Gambar 8 (Fan, et. al., 2011). (a) $\mathrm{P}^{25-\mathrm{TiO}_{2}}$

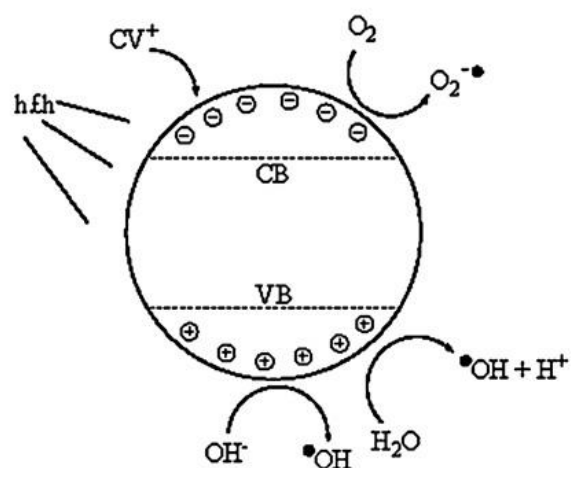

(b) $\mathrm{Pt}-\mathrm{TiO}_{2}$

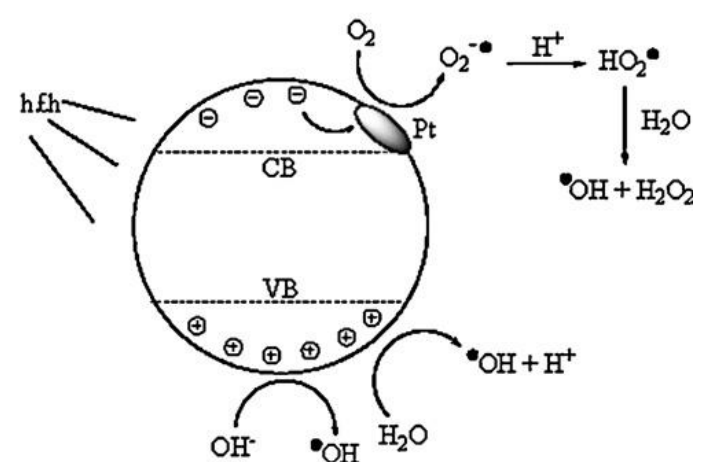

Gambar 8. Ilustrasi pengaruh platina pada titanium(IV) oksida Degussa P25 dalam proses fotodegradasi (Fan, et. a., 2011). 
Berdasarkan hasil pengukuran nilai COD dengan menggunakan titanium(IV) oksida-platina setelah iradiasi 3 jam penurunan nilai COD titanium(IV) oksida-platina $0,5 \%$ lebih tinggi dibanding titanium(IV) oksida platina $1 \%$ hal ini karena terdapat kejenuhan electron pada permukaan fotokatalis titanium(IV) oksida-platina $1 \%$ setelah iradiasi 3 jam sehingga laju fotodegradasi menurun dan terjadi rekombinasi antara electron dan hole. Tetapi setelah iradiasi 4 jam laju fotodegradasi titanium(IV) oksida-platina $1 \%$ menjadi lebih baik dibanding titanium(IV) oksida-platina $0,5 \%$.

\section{KESIMPULAN}

Fotokatalis titanium(IV) oksidaplatina dengan konsentrasi platina $0,5 \%$ dan $1 \%$ dapat disintesis dengan metode impregnasi. Fotokatalis titanium(IV) oksida-platina juga memiliki aktivitas fotodegradasi sipermetrin lebih baik dibanding titanium(IV) oksida yang dapat menurunkan COD hingga $79 \%$.

\section{UCAPAN TERIMA KASIH}

Kepada Fakultas Matematika dan Ilmu Pengetahuan Alam Universitas Padjadjaran yang mendanai hibah kompetitif penelitian FMIPA 2014.

\section{DAFTAR PUSTAKA}

Fan, H. J., C. Shine, W. L. W. Lee, M. R. Chou and C. C. Chen., 2011, Mechanistic Pathways Difference Between P25-TiO ${ }_{2}$ and $\mathrm{Pt}-\mathrm{TiO}_{2}$ Mediates CV Photodegradation. Journal of Hazardous Vol.185. 227-235.

Girsang, W., 2009,Dampak Negatif Penggunaan Pestisda. http://usitani.wordpress.com/2009/0 2/26/dampak-negatif-penggunaanpestisda.
Kaushik, A., H. R. Sharma, S. Jaun, J. Dawra and C. P. Kaushik., 2010, Pesticides Pollution of River Ghagggar in Haryana, India. Environ. Monit.Assess. Vol. 160.6169.

Khataee, A.R. \& M. B. Kasiri, 2010, Artificial Neural Networks Modeling of Contaminated Water Treatment Processes by Homogeneous and Heterogeneous Nanocatalysis, Journal Molecule Catalysis. A: Chem. Vol. 331. 86100.

Kundua, S., A. Pala and A. K. Dikshitb., 2005, UV Induced Degradation of Herbicide 2, 4-D: Kinetics, Mechanism and Effect of Various Conditions on Degradation. Separation and Purification Technology, Vol. 44.121-129.

Mills-Groninger, F., M. Carpenter and J. P. Osbrone., 2012,Cypermethrine Pathway Map. Manchester College.

Mills A. and S. Le Hunte., 1997, An overview of semiconductor photocatalysis. Journal of Photochemistry and Photobiology A: Chemistry 108: 1-35.

O'Shea, V. A. P,. 2013, The Role of CoCatalyst: Interaction and Synergies with Semiconductors. Design of Advances Photocatalytic Materials for Energy and Environmental Applications.Springer. London.

Wei, P., J. Liu and Z. Li., 2012, Effect of $\mathrm{pH}$ Pt-Loading and Calcination Temperature on the Photocatalytic Hydrogen Production Activity of $\mathrm{TiO}_{2}$ Micropheres Ceramic International. 39. 5387-5391.

Zaleska, A,. 2008, Doped-TiO $2: \quad A$ Review Recent Patents on Engineering. Vol. 2. 157-164. 